\title{
Laboratory Interpretation of Rheumatic Diseases
}

\author{
Altaf Abdulkhaliq and Manal Alotaibi
}

\subsection{Introduction}

Generally the diagnosis of rheumatic diseases is based on a set of clinical, serological, and radiological measures. The discovery of a novel test that appears to be considerably more diseasespecific and preferably sensitive would be of value for the early diagnosis and immediate, effective therapy to prevent joint deterioration, functional disability, and unfavorable disease outcome [1].

However, components of acute phase reaction proteins such as erythrocyte sedimentation rate (ESR) and C-reactive protein (CRP) or rheumatoid factor (RF) lack specificity and sensitivity and could not reach the expectation of earlier diagnosis of specific rheumatic diseases. Therefore, the discovery of immunologic laboratory tests has occupied a valued position in the practice of rheumatology and has helped define the pathophysiology of various rheumatic conditions such as the immunologic basis of rheumatoid arthritis (RA) [2,3] and explain the contribution of genetic basis to autoimmune

A. Abdulkhaliq $(\bowtie)$

College of Medicine, Umm Al-Qura University,

Makkah, Saudi Arabia

e-mail: aaabdulkhaliq@uqu.edu.sa

M. Alotaibi

Northwestern University Feinberg School of Medicine, Chicago, IL, USA

Internal Medicine Department, College of Medicine, Umm Al-Qura University, Makkah, Saudi Arabia disease via the association of ankylosing spondylitis (AS) with HLA-B27 and RA with certain HLA-DR alleles [4, 5].

Hence the salient existence of such immunologic laboratory tests has assisted the more precise diagnosis of diverse rheumatologic conditions that may share some clinical characteristics. In addition, these tests can provide valuable evidence concerning disease manifestation, activity and prognosis, and therapeutic monitoring.

Essential terms concerning the laboratory tests are needed to be defined such as sensitivity, specificity, and positive and negative predictive values. Sensitivity refers to the ability of the test to detect the proportion of patients with a disease which usually have a positive test result. However, specificity refers to the ability of the test to detect the proportion of patients without the disease which usually have a negative test result. Predictive value refers to the likelihood of disease or nondisease based on a positive or negative test result. A high positive predictive value test indicates that the patient with a positive test result most probably has the disease in question. Similarly, a high negative predictive value test indicates that the patient with a negative test result most likely does not have the disease in question.

Unlike with sensitivity and specificity of the test, the predictive value is markedly affected by disease prevalence. For instance, the predictive value of a positive rheumatologic test in patients with polyarthralgia is likely to be higher in a rheumatology clinic than in a family physician's clinic [6]. 
The subsequent sections will discuss the stepwise approach to the diagnostic workup of rheumatic diseases and are presented as follows:

- Inflammatory markers (ESR and CRP)

- Rheumatoid factor (RF)

- Antinuclear antibody (ANA) profile, for instance, anti-double-stranded DNA antibodies (anti-dsDNA) and anti-ribonucleic protein (RNP) antibodies

- Other disease-specific antinuclear antibodies and cytoplasmic antibodies

- Complement deficiencies and decreased complement activity in certain medical conditions

- Components and classification of synovial fluid analysis

- Other biochemical tests: renal function tests and urine analysis (this section is not in the scope of the current chapter but it will be discussed in details in the chapter of "Renal System and Rheumatology")

\subsubsection{Objectives}

By the end of the current chapter, the candidates should be able to:

- Identify the rule of acute phase reaction proteins in rheumatic diseases.

- Interpret the auto-antibodies' results based on clinical findings.

- Classify various types of joint effusions based on clinical and laboratory analysis of synovial fluid.

\subsection{Acute Phase Reactants}

Acute phase reactants (APRs) or proteins are defined as those proteins whose serum concentrations increase or decrease by at least $25 \%$ during inflammatory states. Changes in levels of APR largely result from the effects of cytokines, including interleukin (IL)-6, IL-1 beta, tumor necrosis factor-alpha (TNF-alpha), and interferon gamma.
Serum APR level measurements are useful because they frequently reflect the presence and intensity of an inflammatory process. The assessment of APR may be most helpful in patients with RA, polymyalgia rheumatica, and giant cell arteritis.

However, APR measurements in clinical use are not specific to any particular disease.

The most widely used indicators of the acute phase response are the ESR and CRP [7].

ESR and CRP definitions, measurements, uses, and other important aspects are addressed in Table 3.1.

\subsection{Rheumatoid Factor (RF) and Anti-citrullinated Protein Antibody (ACPA)}

\subsubsection{Definition}

$\mathrm{RF}$ is an antibody directed against the Fc fragment of immunoglobulin $\mathrm{G}(\mathrm{IgG})$. It may be of any isotype: $\operatorname{IgG}, \operatorname{IgA}, \operatorname{IgE}$, and $\operatorname{IgM}$. RF- $\operatorname{IgM}$ is the only one measured in clinical practice. The origin of RF is incompletely understood [7]. ACPAs are antibodies that are targeted against citrulline which is situated on proteins. Important clinical features of RF including measurement and common issues while dealing with it in clinical practice are all addressed in Table 3.2.

\subsection{Antinuclear Antibodies (ANAs)}

\subsubsection{Definition}

ANAs are serologic hallmarks of patients with systemic autoimmune disease. These antibodies should be ordered when the clinical assessment of the patient suggests the presence of an autoimmune or connective tissue diseases [7]. Clinical aspects of ANAs are discussed in Table 3.3. 
Table 3.1 ESR versus CRP

\begin{tabular}{|c|c|c|c|}
\hline \multirow[t]{2}{*}{ Definition } & \multicolumn{2}{|l|}{ ESR } & CRP \\
\hline & \multicolumn{2}{|c|}{$\begin{array}{l}\text { ESR is an indirect measurement of serum acute phase protein } \\
\text { concentrations, defined as the rate ( } \mathrm{mm} / \text { hour) at which erythrocytes } \\
\text { suspended in plasma settle when placed in a vertical tube, reflects a } \\
\text { variety of factors, most notably the plasma concentration of } \\
\text { fibrinogen [7] }\end{array}$} & $\begin{array}{l}\text { CRP is defined as a } \\
\text { pentameric protein } \\
\text { comprised of five } \\
\text { identical, non-covalently } \\
\text { linked 23-KD subunits } \\
\text { arranged in cyclic } \\
\text { symmetry in a single } \\
\text { plane. It is a component } \\
\text { of the innate immune } \\
\text { response and has both } \\
\text { pro-inflammatory and } \\
\text { anti-inflammatory } \\
\text { actions. CRP can activate } \\
\text { the complement system } \\
\text { and enhance the } \\
\text { apoptotic cell clearance } \\
\text { [7] }\end{array}$ \\
\hline \multirow{3}{*}{$\begin{array}{l}\text { Methods of } \\
\text { measurement }\end{array}$} & \multicolumn{2}{|l|}{ Cont. ESR } & Cont. CRP \\
\hline & The Westergren method & The Wintrobe method & \multirow{2}{*}{$\begin{array}{l}\text { It is measured by } \\
\text { immunoassay technique } \\
\text { or nephelometry [7] }\end{array}$} \\
\hline & $\begin{array}{l}\text { Uses a } 200-\mathrm{mm} \text { tube and has a } \\
\text { dilution step that correct for the effect } \\
\text { of anemia. } \\
\text { It is the preferred method and can } \\
\text { detect an ESR more than } \\
50-60 \mathrm{~mm} / \mathrm{h}[7,8]\end{array}$ & $\begin{array}{l}\text { Uses a } 100-\mathrm{mm} \text { tube and has } \\
\text { no dilution step }[7,8]\end{array}$ & \\
\hline \multirow[t]{2}{*}{$\begin{array}{l}\text { Sensitivity } \\
\text { and specificity }\end{array}$} & \multicolumn{2}{|c|}{$\begin{array}{l}\text { An advanced rate does not diagnose a specific disease, but it does } \\
\text { indicate that an underlying disease may exist }[7,8]\end{array}$} & $\begin{array}{l}\text { Although CRP is a } \\
\text { sensitive reflector of } \\
\text { inflammation, it is not } \\
\text { specific for inflammation } \\
\text { [9] }\end{array}$ \\
\hline & \multicolumn{3}{|c|}{$\begin{array}{l}\text { An elevated ESR observed together with a normal CRP is often a false-positive value for the ESR; } \\
\text { this may reflect the effects of blood constituents, such as monoclonal immunoglobulins, that are } \\
\text { not related to inflammation but that can influence the ESR. However, this conclusion is not always } \\
\text { valid. As an example, the ESR may be markedly elevated in patients with active systemic lupus } \\
\text { erythematosus (SLE), while the CRP response is muted. These variations may be explained by } \\
\text { differences in the production of specific cytokines or their modulators in different diseases [10] }\end{array}$} \\
\hline Normal result & $\begin{array}{l}\text { - Normal values for the Westergren } \\
\text { method are: } \\
\text { Men }=0-15 \mathrm{~mm} / \mathrm{h} \\
\text { Women }=0-20 \mathrm{~mm} / \mathrm{h} \\
\text { Children }=0-10 \mathrm{~mm} / \mathrm{h} \\
\text { - A normal value does not rule out } \\
\text { the disease } \\
\text { - Non-inflammatory conditions that } \\
\text { can elevate ESR include aging, } \\
\text { female sex, obesity, pregnancy, and } \\
\text { race }[7,8] \\
\text { - The age-adjusted upper limit of } \\
\text { normal for ESR is: } \\
\text { Male }=\text { age } / 2 \\
\text { Female }=(\text { age }+10) / 2\end{array}$ & $\begin{array}{l}\text { - Normal value is less than } 0 . \\
\text { - CRP levels vary with age, } \mathrm{s} \\
\text { - The age-adjusted upper lim } \\
\text { Male }=\text { age in years } / 50 \\
\text { Female }=(\text { age in years } / 50)+\end{array}$ & $\begin{array}{l}\text { mg/dl } \\
\text { of normal for CRP is: } \\
6 \text { [9] }\end{array}$ \\
\hline
\end{tabular}


Table 3.1 (continued)

\begin{tabular}{|c|c|c|}
\hline \multirow[t]{3}{*}{$\begin{array}{l}\text { Abnormal } \\
\text { results }\end{array}$} & \multirow{3}{*}{$\begin{array}{l}\text { 1-Causes of marked ESR elevation } \\
\text { (more than } \mathbf{1 0 0} \mathbf{~ m m / h r ) : ~} \\
\text { 1. Infection (bacterial } 33 \% \text { ) } \\
\text { 2. Connective tissue diseases (gain } \\
\text { cell arteritis, polymyalgia } \\
\text { rheumatica, SLE, vasculitides } \\
\text { 25\%) } \\
\text { 3. Malignant neoplasms and renal } \\
\text { disease } 17 \% \\
\text { 4. Inflammatory disorders } 14 \% \text { [7, } \\
\text { 11] } \\
\text { Causes of marked decreased in } \\
\text { ESR (0 mm/h): } \\
\text { 1. Afibrinogenemia/ } \\
\text { dysfibrinogenemia } \\
\text { 2. Agammaglobulinemia } \\
\text { 3. Increased plasma viscosity } \\
\text { 4. Extreme polycythemia [7, 11] }\end{array}$} & $\begin{array}{l}\text { Values between } \mathbf{0 . 3} \text { and } \mathbf{1} \mathbf{~ m g} / \mathbf{d L} \text { may indicate: } \\
\text { 1. Minor degrees of inflammation, e.g., periodontitis } \\
\text { 2. Minor degrees of metabolic malfunction (non- } \\
\text { inflammatory states), e.g., obesity and insulin } \\
\text { resistance }[7,9]\end{array}$ \\
\hline & & $\begin{array}{l}\text { Values greater than } \mathbf{1} \mathbf{~ m g} / \mathbf{d L} \text { can indicate: } \\
\text { Clinically significant inflammation [9] }\end{array}$ \\
\hline & & $\begin{array}{l}\text { Values greater than } \mathbf{8 - 1 0} \mathbf{~ m g / d L ~ m a y ~ i n d i c a t e : ~} \\
\text { 1. Bacterial infection } \\
\text { 2. Systemic vasculitis } \\
\text { 3. Metastatic cancer } \\
\text { 4. Trauma, burns, and surgery }[7,9]\end{array}$ \\
\hline \multirow[t]{2}{*}{$\begin{array}{l}\text { Advantages } \\
\text { and } \\
\text { disadvantages }\end{array}$} & $\begin{array}{l}\text { 1. Inexpensive, familiar, and easy to } \\
\text { perform } \\
\text { 2. As a patient's condition worsens } \\
\text { or improves, the ESR changes are } \\
\text { relatively slow [12] } \\
\text { 3. A literature review was conducted } \\
\text { for all clinical trials and } \\
\text { observational studies of disease- } \\
\text { modifying medications and } \\
\text { corticosteroids in RA to elaborate } \\
\text { on the laboratory results of both } \\
\text { ESR and CRP before treatment } \\
\text { and } 4 \text { weeks to } 24 \text { weeks after } \\
\text { treatment in the same patients, and } \\
\text { it has been concluded that the ESR } \\
\text { was more sensitive to change than } \\
\text { the CRP at } 12 \text { weeks and } \\
24 \text { weeks of treatment [13] }\end{array}$ & $\begin{array}{l}\text { 1. It rises more quickly and falls more quickly than ESR } \\
\text { [11] } \\
\text { 2. Measurements of CRP concentrations are of prognostic } \\
\text { value in rheumatoid arthritis and can help guide } \\
\text { management [11,13-15] } \\
\text { 3. CRP alone may have been in favor as a simple, } \\
\text { validated, reproducible, non-age-dependent test for } \\
\text { disease activity assessment [12] } \\
\text { 4. CRP had been found to be more sensitive and specific } \\
\text { marker for diagnosing bacterial infections in SLE } \\
\text { compared to procalcitonin (PCT) [14, 15]. However, } \\
\text { further meta-analysis report of studies describing the } \\
\text { role of PCT or CRP as a biomarker of infection in } \\
\text { autoimmune diseases has determined that PCT test is } \\
\text { more specific than sensitive [16]. In addition, a later } \\
\text { study has confirmed that PCT test is superior to CRP } \\
\text { test in detecting superimposed bacterial infections in } \\
\text { active SLE patients, where the PCT levels are correlated } \\
\text { with the progression of bacterial infection and used to } \\
\text { monitor the response to antibiotic treatment [17] }\end{array}$ \\
\hline & \multicolumn{2}{|c|}{$\begin{array}{l}\text { The serum protein electrophoresis is the most sensitive test for detecting inflammatory changes. } \\
\text { It is the most expensive, directly quantifies the acute phase response [7]. However, there is no } \\
\text { single best laboratory test to reflect inflammation } \\
\text { The optimal use of acute phase protein measurements may be to obtain several measurements, } \\
\text { most commonly ESR and CRP, rather than a single test }[9,14,18] \\
\text { Additional tests suggest systemic inflammation: Low albumin and mild elevation of hepatic } \\
\text { alkaline phosphatase [7] }\end{array}$} \\
\hline
\end{tabular}

\subsubsection{Methods of Measurement}

- Indirect immunofluorescence method using "fluorescence microscope" is the gold standard method to detect ANAs. Currently most laboratories use human epithelial cell tumor line (HEp2 cells) as a substrate to detect anti- bodies that bind to various nuclear antigens (ANAs) instead of frozen section of rodent organ cells.

- Other methods that can be used for detection of specific ANA include ELISA, immuno-blotting, and Western-blotting methods. 
Table 3.2 Characteristics of RF

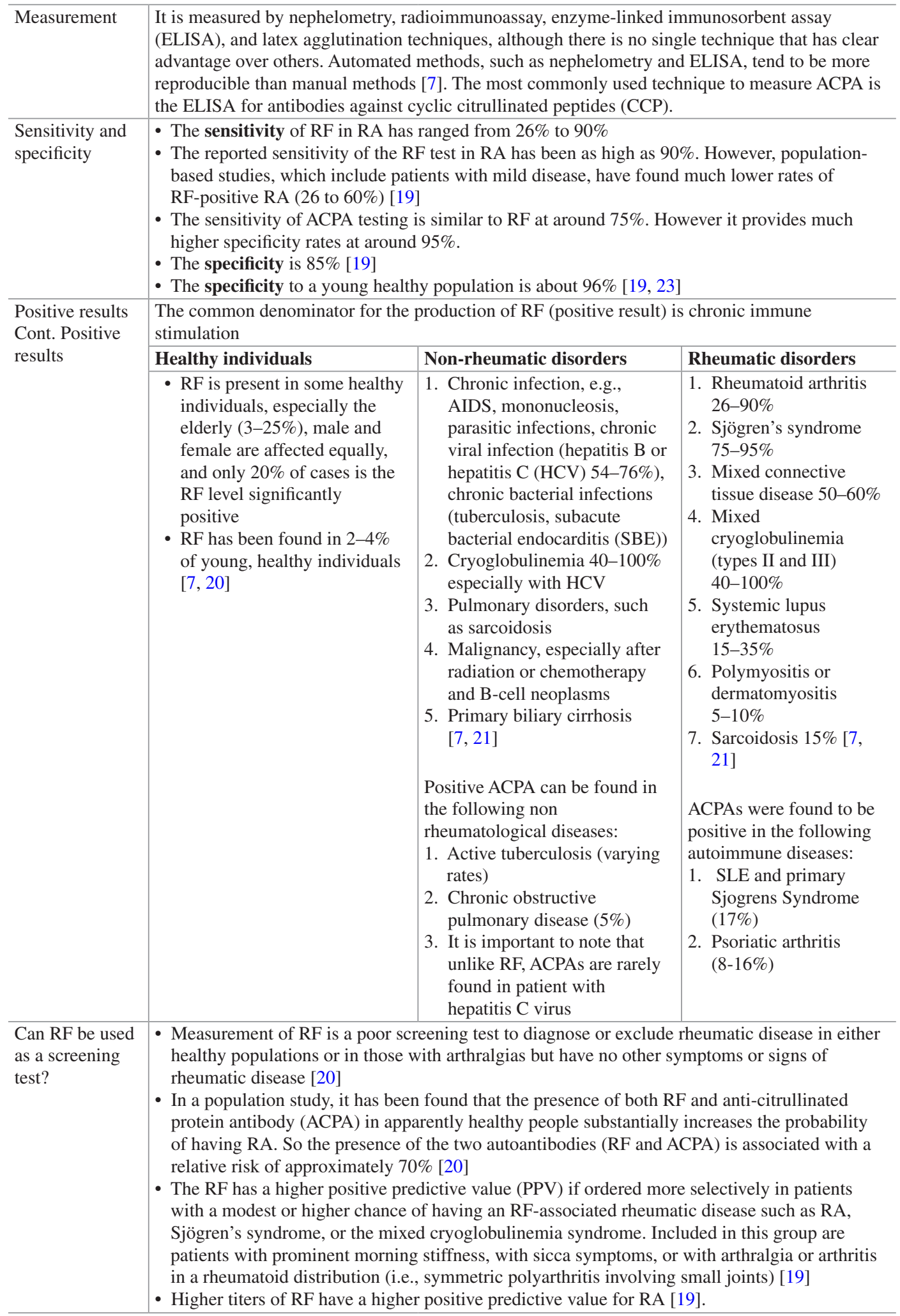


Table 3.2 (continued)

\begin{tabular}{|c|c|}
\hline $\begin{array}{l}\text { Significance of } \\
\text { measuring RF } \\
\text { and ACPA in } \\
\text { known RA } \\
\text { cases }\end{array}$ & $\begin{array}{l}\text { - RF-positive patients with RA may experience more aggressive and erosive joint disease and } \\
\text { extra-articular manifestations than those who are RF-negative. Similar findings have been } \\
\text { observed in juvenile idiopathic arthritis [19] } \\
\text { - RF status may be useful in combination with other indicators, including HLA-DRB1, CRP, } \\
\text { the ESR, and severity of synovitis on physical exam, to predict progression of radiographic } \\
\text { changes in RA patients and to guide treatment [19] } \\
\text { - ACPA positivity was found to be associated with more erosive joint disease, especially } \\
\text { apparent on radiographs. It was also found to be better at predicting these changes than RF }\end{array}$ \\
\hline $\begin{array}{l}\text { RF and } \\
\text { monitoring of } \\
\text { rheumatic } \\
\text { diseases }\end{array}$ & $\begin{array}{l}\text { - The change in RF level does not reflect changes in RA disease activity } \\
\text { - RF should not be used routinely to monitor RA disease activity in clinical practice } \\
\text { - RF titer may fall with effective treatment of RA in patients who are originally RF-positive } \\
{[19,22]} \\
\text { - In Sjögren's syndrome, the disappearance of a previously positive RF may herald the onset of } \\
\text { lymphoma. That is why some clinicians check RF repeatedly in patients with Sjögren's } \\
\text { syndrome. The clinical utility of this practice, however, has not been critically assessed [19, } \\
22]\end{array}$ \\
\hline $\begin{array}{l}\text { Antibody status } \\
\text { (ACPA/RF) }\end{array}$ & $\begin{array}{l}\text { - RF and ACPA have the potential to revert and convert during the early course of disease. } \\
\text { Fluctuations in RF and ACPA were not associated with clinical outcomes [23] } \\
\text { - Repeated measurement of ACPA or RF during the first year after onset of arthritis does not } \\
\text { offer major additional information [24] }\end{array}$ \\
\hline $\begin{array}{l}\text { RF and the } \\
\text { mortality }\end{array}$ & $\begin{array}{l}\text { Patients with RA with positive RF, especially IgA and IgM isotypes, carry a risk of dying earlier } \\
\text { than patients without these serological findings [25] }\end{array}$ \\
\hline
\end{tabular}

Table 3.3 ANA characteristics

\begin{tabular}{|c|c|c|c|c|}
\hline \multirow[t]{3}{*}{$\begin{array}{l}\text { Positive } \\
\text { result }\end{array}$} & \multicolumn{4}{|c|}{$\begin{array}{l}\text { - It is defined as the level of ANA that exceeds the level seen in } 95 \% \text { of the normal population } \\
\text { - In most laboratories, this level is a titer of 1:40 to 1:80 that are reported positive } \\
\text { - Clinically significant titers in laboratories that use HEp- } 2 \text { cells as substrate are usually more than or equal to } 1: 160 \\
{[7,26]}\end{array}$} \\
\hline & $\begin{array}{l}\text { Systemic autoimmune } \\
\text { diseases }\end{array}$ & Organ-specific autoimmune diseases & Infections & Others \\
\hline & $\begin{array}{l}\text { 1. SLE 93\% } \\
\text { 2. Scleroderma } 85 \% \\
\text { 3. Mixed connective } \\
\text { tissue disease } 93 \% \\
\text { 4. Polymyositis/ } \\
\text { dermatomyositis } \\
61 \% \\
\text { 5. Rheumatoid arthritis } \\
41 \% \\
\text { 6. Rheumatoid } \\
\text { vasculitis 33\% } \\
\text { 7. Sjögren's syndrome } \\
\text { 48\% } \\
\text { 8. Drug-induced lupus } \\
\text { 95-100\%; (e.g., } \\
\text { procainamide, } \\
\text { hydralazine, } \\
\text { isoniazid, and } \\
\text { quinidine) } \\
\text { 9. Discoid lupus 15\% } \\
\text { 10. Pauci-articular } \\
\text { juvenile chronic } \\
\text { arthritis } 71 \% \text { [7, } \\
\text { 26] }\end{array}$ & $\begin{array}{l}\text { 1. Hashimoto's thyroiditis } 46 \% \\
\text { 2. Graves' disease } 50 \% \\
\text { 3. Autoimmune hepatitis } 63-91 \% \\
\text { 4. Primary biliary cirrhosis } 10-40 \% \\
\text { 5. Primary autoimmune cholangitis } \\
100 \% \\
\text { 6. Idiopathic pulmonary arterial } \\
\text { hypertension } 40 \% \\
\text { 7. Multiple sclerosis } 25 \%[7,26]\end{array}$ & $\begin{array}{l}\text { - Chronic infectious } \\
\text { diseases } \\
\text { (mononucleosis, } \\
\text { hepatitis C } \\
\text { infection, SBE, } \\
\text { tuberculosis, and } \\
\text { HIV) and some } \\
\text { lympho- } \\
\text { proliferative } \\
\text { diseases } \\
\text { - Malignancy (rare) } \\
\text { with the exception } \\
\text { of dermatomyositis } \\
{[7,26]}\end{array}$ & $\begin{array}{l}\text { 1. Highly relatives of } \\
\text { patient } 15-25 \% \\
\text { 2. Normal elderly } \\
20 \% \\
\text { 3. Patients with } \\
\text { silicone breast } \\
\text { implant } 15-25 \% \\
\text { [7] }\end{array}$ \\
\hline $\begin{array}{l}\text { Is ANA } \\
\text { used as a } \\
\text { screening } \\
\text { test? }\end{array}$ & \multicolumn{4}{|c|}{$\begin{array}{l}\text { - No, it cannot be used as a screening test for autoimmune disorders in the general healthy population in the absence } \\
\text { of clinical findings as it may be present in very low specificity titer in normal population 5\% } \\
\text { - It should be used primarily as a confirmatory test when the clinicians strongly suspect SLE or autoimmune } \\
\text { disorders } \\
\text { - A patient with a negative ANA and strong clinical evidence of SLE or another SS-A-associated disease, antibodies } \\
\text { to SS-A should be ordered [7] }\end{array}$} \\
\hline
\end{tabular}


Table 3.2 (continued)

\begin{tabular}{|c|c|c|c|c|c|}
\hline $\begin{array}{l}\text { Is ANA } \\
\text { used for } \\
\text { monitoring } \\
\text { diseases? }\end{array}$ & \multicolumn{5}{|c|}{$\begin{array}{l}\text { - No, there is no evidence about use of ANA titer as a monitor to follow disease activity in patients with SLE and } \\
\text { autoimmune diseases [7] }\end{array}$} \\
\hline \multirow[t]{2}{*}{$\begin{array}{l}\text { ANA } \\
\text { patterns }\end{array}$} & \multicolumn{5}{|c|}{$\begin{array}{l}\text { The pattern type has been found to have relatively low sensitivity and specificity for different autoimmune disorders, } \\
\text { and thus tests for specific antibodies have largely replaced the use of patterns }\end{array}$} \\
\hline & $\begin{array}{l}\text { The homogeneous or } \\
\text { diffuse pattern } \\
\text { Represents antibodies to } \\
\text { the DNA-histone } \\
\text { complex (anti-DNP (LE } \\
\text { cell) and anti-histone) }\end{array}$ & $\begin{array}{l}\text { The peripheral or } \\
\text { rim pattern } \\
\text { It is produced by } \\
\text { antibodies to DNA } \\
\text { (anti-dsDNA) and } \\
\text { antibodies to } \\
\text { nuclear envelope } \\
\text { antigens } \\
\text { (anti-laminin) }\end{array}$ & $\begin{array}{l}\text { The speckled } \\
\text { pattern } \\
\text { It is produced by } \\
\text { antibodies to } \\
\text { SM, RNP, Ro/ } \\
\text { SSA, La/SSB, } \\
\text { Scl-70, } \\
\text { centromere, } \\
\text { proliferating cell } \\
\text { nuclear antigen } \\
\text { (PCNA), and } \\
\text { other antigens }\end{array}$ & $\begin{array}{l}\text { The nucleolar } \\
\text { pattern } \\
\text { It is produced by } \\
\text { antibodies to RNA } \\
\text { polymerase I, } \\
\text { proteins of the small } \\
\text { nucleolar RNP } \\
\text { complex (fibrillarin, } \\
\text { Mpp10, and } \\
\text { hU3-55 K), Th/to, } \\
\text { B23, PM-Scl, and } \\
\text { NOR-90, and other } \\
\text { antigens }\end{array}$ & $\begin{array}{l}\text { The centromeric } \\
\text { pattern } \\
\text { It is produced by } \\
\text { antibodies to proteins } \\
\text { that are associated } \\
\text { with the site of } \\
\text { chromosomal } \\
\text { constriction. Proteins } \\
\text { designated, CENP-A, } \\
\text { CENP-B, CENP-C, } \\
\text { etc., are only present } \\
\text { on active centromeres } \\
\text { (i.e., during meiosis } \\
\text { and mitosis) [7, 26] }\end{array}$ \\
\hline \multirow[t]{2}{*}{ ANA titer } & \multicolumn{5}{|c|}{$\begin{array}{l}\text { - The presence of very high concentrations of antibody (titer }>1: 640 \text { ) should arouse suspicion of an autoimmune } \\
\text { disorder. However, its presence alone is not diagnostic of disease } \\
\text { - If no initial diagnosis can be made, it is our practice to watch the patient carefully over time and to exclude } \\
\text { ANA-associated diseases } \\
\text { - An accurate ANA with titer, in combination with a full history and physical examination, can be extremely useful } \\
\text { in the diagnosis and exclusion of connective tissue disease [26] }\end{array}$} \\
\hline & \multicolumn{5}{|c|}{$\begin{array}{l}\text { - 1-2\% of patients who have active and untreated SLE will have a negative ANA, and this is because the substrate } \\
\text { used in ANA test did not contain a sufficient antigen to detect SS-A antibodies } \\
-10-15 \% \text { of SLE patients will become ANA-negative with treatment or inactive disease } \\
-40-50 \% \text { of SLE patients with end-stage renal disease on dialysis will become an ANA-negative [7] }\end{array}$} \\
\hline
\end{tabular}

\subsection{ANA Profile}

\subsubsection{Definition}

An ANA profile consists of many antibodies to measure specific ANAs for certain nuclear antigens. It should be performed when the screening test for ANA is positive and when further information is needed regarding the type of autoimmune disorder [7].

ANA profile antibodies and their specific uses are elaborated on Table 3.4.

\subsection{Other Disease-Specific Antinuclear Antibodies and Cytoplasmic Antibodies}

These antibodies have to be ordered individually according to the set-up diagnosis based on patient's symptoms and clinical presentations, and they include:
1. Anti-histone antibodies: sensitive (70\%) for drug-induced lupus but nonspecific and have limited diagnostic utility because they may also be present in patients with SLE. The best test to conduct in patient with suspected druginduced lupus is antichromatin antibody test, not anti-histone antibody test [7]. However, anti-histone antibody test might be of value in patients having a positive ANA test with history of exposure to medications-induced lupus, such as procainamide (Pronestyl) and isoniazid (INH) [27].

2. Anti-Th/To antibodies: crest syndrome $20 \%$ [7].

3. Anti-SCL-70 antibodies (topoisomerase1): diffuse systemic sclerosis (scleroderma) 22-40\% [7]. They are highly specific but not sensitive for scleroderma [29].

4. Anti-tRNA synthetase antibodies (antiJo-1, other): polymyositis 20-30\% [7].

5. Anti-neutrophil cytoplasmic antibodies (ANCAs): 
Table 3.4 The standard ANA profile

\begin{tabular}{|c|c|c|}
\hline $\begin{array}{l}\text { Measured } \\
\text { antibodies }\end{array}$ & $\begin{array}{l}\text { Associated } \\
\text { diseases }\end{array}$ & Characteristics \\
\hline $\begin{array}{l}\text { Anti-dsDNA } \\
\text { antibodies } \\
\text { (directed } \\
\text { against } \\
\text { double- } \\
\text { stranded } \\
\text { DNA) }\end{array}$ & SLE $60 \%$ & $\begin{array}{l}\text { - It is very specific } \\
\text { for SLE } \\
\text { - It is the one that } \\
\text { used to follow } \\
\text { SLE disease } \\
\text { activity; high } \\
\text { titers are } \\
\text { associated with } \\
\text { lupus nephritis or } \\
\text { a flare of lupus } \\
\text { activity [27] }\end{array}$ \\
\hline $\begin{array}{l}\text { Anti-U1 RNP } \\
\text { antibodies } \\
\text { (ribonuclear } \\
\text { protein) }\end{array}$ & $\begin{array}{l}\text { SLE } 30 \%, \\
\text { progressive } \\
\text { systemic } \\
\text { sclerosis (low } \\
\text { titer), and mixed } \\
\text { connective } \\
\text { tissue disease } \\
\text { (MCTD) }\end{array}$ & $\begin{array}{l}\text { - A very high level } \\
\text { of this antibody } \\
\text { is highly } \\
\text { suggestive of } \\
\text { MCTD [28] }\end{array}$ \\
\hline $\begin{array}{l}\text { Anti-SM } \\
\text { (smith) } \\
\text { antibodies }\end{array}$ & SLE $30 \%$ & $\begin{array}{l}\text { - It is very specific } \\
\text { for SLE } \\
\text { - The sensitivity } \\
\text { of anti-dsDNA } \\
\text { and anti-Sm for } \\
\text { the diagnosis of } \\
\text { SLE is relatively } \\
\text { low } \\
\text { - Anti-Sm } \\
\text { antibodies } \\
\text { generally remain } \\
\text { positive, even } \\
\text { when a patient } \\
\text { has entered } \\
\text { remission; } \\
\text { therefore it may } \\
\text { be especially } \\
\text { useful } \\
\text { diagnostically } \\
\text { when a SLE } \\
\text { patient's disease } \\
\text { is relatively } \\
\text { inactive [28] }\end{array}$ \\
\hline $\begin{array}{l}\text { Anti-SS-A } \\
\text { (RO) } \\
\text { antibodies }\end{array}$ & $\begin{array}{l}\text { SLE } 30 \%, \\
\text { primary } \\
\text { Sjögren's } \\
\text { syndrome } 70 \% \text {, } \\
\text { neonatal lupus, } \\
\text { sub-acute } \\
\text { cutaneous lupus } \\
\text { (SCLE), } \\
\text { secondary } \\
\text { Sjögren's } \\
\text { syndrome (rare) } \\
\text { [28] }\end{array}$ & \\
\hline
\end{tabular}

Table 3.4 (continued)

\begin{tabular}{l|l|l}
\hline $\begin{array}{l}\text { Measured } \\
\text { antibodies }\end{array}$ & $\begin{array}{l}\text { Associated } \\
\text { diseases }\end{array}$ & Characteristics \\
\hline $\begin{array}{l}\text { Anti-SS-B } \\
\text { (LA) }\end{array}$ & $\begin{array}{l}\text { SLE 15\%, } \\
\text { Sjögren's } \\
\text { antibodies }\end{array}$ & $\begin{array}{l}\text { syndrome 60\% } \\
{[28]}\end{array}$ \\
\hline $\begin{array}{l}\text { Anti- } \\
\text { centromere } \\
\text { antibodies }\end{array}$ & $\begin{array}{l}\text { Crest syndrome } \\
98 \%, \text { diffuse } \\
\text { scleroderma }\end{array}$ & \\
& $22-36 \%[28]$ & \\
\hline
\end{tabular}

- Cytoplasmic anti-neutrophil cytoplasmic antibodies (C-ANCA), the most common c-ANCA target is serine proteinase-3: granulomatous polyangiitis (GPA) (Wegener granulomatosis) $90 \%$, microscopic polyangiitis (MPA), eosinophilic granulomatosis with polyangiitis (EGPA) (rare). Its titer can correlate with GPA disease activity [30].

- Perinuclear anti-neutrophil cytoplasmic antibodies (P-ANCA), the most common p-ANCA target is myeloperoxidase: MPA $70 \%$, pauci-immune glomerulonephritis, and EGPA, or myeloperoxidase (-) ulcerative colitis, chronic infection, and neoplasm (rare) [30].

6. Anti-mitochondrial antibodies (AMAs): primary biliary cirrhosis $80 \%$ [7].

7. Antibodies to the gp210 and p62 proteins of the nuclear pore complex: primary biliary cirrhosis $10-40 \%$ [7].

\subsection{Circulatory Complement Components}

Complement is an important effector pathway of innate immunity and has a role in the pathogenesis of some of rheumatic conditions, namely, SLE.

\section{Causes of Decreased Circulatory Complement Components}

- Hereditary complement deficiencies (decreased production)

- Secondary complement deficiencies (acquired) [31] 


\subsubsection{Mechanism of Acquired Complement Deficiencies}

1. Increased level of circulatory immune complexes (increased consumption of complements) due to:

- Infectious causes

- Glomerulonephritis

- Rheumatic diseases:

(a) SLE: Low C4 and C3 levels occur in about $50 \%$ of patients with SLE. Levels of $\mathrm{C} 3$ and $\mathrm{C} 4$ are decreased with increased severity of SLE, especially renal disease. A return to normal levels with treatment is a good prognostic sign. Serial observations reveal decreased levels preceding clinical exacerbation.

(b) Cryoglobulinemia: The complement profile shows decreased levels of $\mathrm{C} 4$ and C2 with normal or slightly lowered C3.

(c) Systemic vasculitis especially polyarteritis nodosa, urticarial vasculitis: $50 \%$ of patients with polyarteritis may have decreased serum complement levels. Its values can be helpful in assessing the clinical course, especially the response to therapy.

(d) RA with extra-articular manifestation (rare) [7, 32].

2. Reduced hepatic synthesis (uncommon)

3. Loss of complement components in the urine (rare) [30]

\subsection{Synovial Fluid Analysis}

The presentation of one or more hot, swollen joints is a common medical emergency, and synovial fluid aspiration, the so-called arthrocentesis, is the single most important test helping in the diagnosis of different types of arthropathies [33].

Therefore, specialized laboratories analyze synovial fluid to either confirm the diagnosis of crystal-associated arthropathies, support the diagnosis of septic arthritis, or establish other rheumatologic diagnoses such as mono-arthritis or joint effusion [34].
The complete analysis of synovial fluid includes macroscopic (gross appearance), microscopic, and specific stain tests to provide detailed information about the joint's condition and helps in establishing the diagnosis and treatment [35]. Description of macroscopic analysis of synovial fluid includes color, clearance, volume, and viscosity. However, the microscopic analysis can differentiate between inflammatory and infectious processes by measuring a complete leukocyte count. In addition, a differential of the synovial WBC count should be ordered, so that if the results came positive for infectious process, the performance of Gram-stain and culture tests will provide guidance to diagnosis and/or antibiotic therapy [36].

Microscopic examination specifically can also allow the detection and identification of various types of crystal by using polarized light microscope. Refer to Table 3.5 for an overview on important issues as regards arthrocentesis and synovial fluid analysis. However, Table 3.6 shows the classification of joint effusions into normal, inflammatory, non-inflammatory, and septic effusion based on clinical and laboratory analysis of synovial fluid with the causes of each type [37, 38]. Indications, contraindications, complications, and specimen analysis of synovial fluid are presented in Table 3.5. Classification and causes of joint effusions based on laboratory analysis of synovial fluid are presented in Table 3.6. Fig. 3.1 is the clinical diagnostic approach for painful peripheral joint.

\subsection{Key Notes}

- The likelihood diagnosis of septic arthritis is markedly increased with higher synovial WBC counts. It has been illustrated that for synovial WBC count the likelihood ratio (LR) of having septic arthritis is as follows [34]:

- WBC count $<25,000 / \mu \mathrm{L}$, the LR is 0.32 at 95\% CI.

- WBC count $\geq 25,000 / \mu \mathrm{L}$ the LR is 2.9 at 95\% CI.

- WBC count $>50,000 / \mu \mathrm{L}$, the LR is 7.7 at 95\% CI. 
Table 3.5 Overview on arthrocentesis and synovial fluid analysis

\begin{tabular}{|c|c|c|c|c|}
\hline Indications & Contraindications & Complications & Specimen handling & Synovial fluid analysis \\
\hline $\begin{array}{l}\text { 1. According to the } \\
\text { American College of } \\
\text { Rheumatology } \\
\text { (ACR), synovial } \\
\text { fluid analysis should } \\
\text { be performed in the } \\
\text { febrile patient with } \\
\text { an acute flare of } \\
\text { established arthritis } \\
\text { to rule out } \\
\text { superimposed septic } \\
\text { arthritis } \\
\text { 2. Unexplained joint, } \\
\text { bursa, or tendon } \\
\text { sheath swelling } \\
\text { 3. Suspected crystal- } \\
\text { induced arthritis } \\
\text { 4. Repeated aspiration } \\
\text { and analysis may be } \\
\text { indicated to follow } \\
\text { up the response of } \\
\text { septic arthritis to } \\
\text { treatment and may } \\
\text { also be valuable for } \\
\text { diagnosis of some } \\
\text { cases of gout in } \\
\text { which the initial } \\
\text { aspirate does not } \\
\text { have detectable } \\
\text { crystals [34] }\end{array}$ & $\begin{array}{l}\text { 1. There is no } \\
\text { absolute } \\
\text { contraindication } \\
\text { 2. Bleeding diatheses } \\
\text { and cellulites are } \\
\text { considered as } \\
\text { relative } \\
\text { contraindication; it } \\
\text { could make the } \\
\text { approach to the } \\
\text { joint space difficult } \\
\text { due to the } \\
\text { overlying swelling } \\
\text { [37] }\end{array}$ & $\begin{array}{l}\text { 1. Infection } \\
\text { 2. Hemarthrosis } \\
\text { 3. Pain } \\
\text { 4. Cartilage } \\
\text { injury } \\
\text { 5. Vasovagal } \\
\text { syncope [37] }\end{array}$ & $\begin{array}{l}\text { 1. Aspiration is } \\
\text { performed } \\
\text { under aseptic } \\
\text { technique with } \\
\text { quick transfer } \\
\text { of specimen for } \\
\text { culture to the } \\
\text { sterile tubes } \\
\text { and plated as } \\
\text { soon as } \\
\text { possible } \\
\text { 2. If the transfer } \\
\text { is delayed } \\
\text { more than } \\
6 \text { hours, many } \\
\text { changes would } \\
\text { occur, for } \\
\text { example, } \\
\text { decrease in } \\
\text { leukocyte } \\
\text { count or } \\
\text { decrease in } \\
\text { crystal } \\
\text { numbers [36] }\end{array}$ & $\begin{array}{l}\text { The WBC count and } \\
\text { the percentage of } \\
\text { PMN cells can help } \\
\text { to differentiate } \\
\text { between non- } \\
\text { inflammatory, } \\
\text { inflammatory, and } \\
\text { septic joint } \\
\text { conditions. These } \\
\text { tests are the best } \\
\text { diagnostic tool } \\
\text { available for } \\
\text { detecting bacterial } \\
\text { arthritis [36] } \\
\text { 1. Gram stain and } \\
\text { cultures should be } \\
\text { ordered even with } \\
\text { relatively low } \\
\text { suspicion of } \\
\text { infection } \\
\text { 2. Crystal search } \\
\text { using polarized } \\
\text { light microscopy } \\
\text { 3. Chemistry } \\
\text { analysis should } \\
\text { not be routinely } \\
\text { ordered [37] }\end{array}$ \\
\hline
\end{tabular}

Table 3.6 Classification and causes of joint effusions based on laboratory analysis of synovial fluid

\begin{tabular}{|c|c|c|c|c|}
\hline Fluid features & Normal & Non-inflammatory & Inflammatory & Pyarthrosis or septic arthrosis \\
\hline Appearance & $\begin{array}{l}\text { Clear, } \\
\text { highly } \\
\text { viscous, } \\
\text { colorless }\end{array}$ & $\begin{array}{l}\text { Clear to slightly } \\
\text { turbid }\end{array}$ & $\begin{array}{l}\text { Slightly turbid, } \\
\text { yellow or } \\
\text { yellow-green }\end{array}$ & $\begin{array}{l}\text { Turbid to very turbid, yellow or } \\
\text { yellow-green }\end{array}$ \\
\hline $\begin{array}{l}\text { Total WBC count/ } \\
\text { MM3 }\end{array}$ & $0-200$ & $200-2000$ & $2000-50,000$ & $50,000-150,000$ \\
\hline $\begin{array}{l}\text { Polymorphonuclear } \\
\text { cell (PMN)\% }\end{array}$ & $<10 \%$ & $<20 \%$ & $20-70 \%$ & $\geq 75 \%$ \\
\hline Causes & & $\begin{array}{l}\text { - Osteoarthritis } \\
\text { - Joint trauma } \\
\text { - Hypertrophic } \\
\text { osteoarthropathy } \\
\text { - Neuropathic } \\
\text { arthropathy } \\
\text { - Avascular } \\
\text { necrosis }[37,38]\end{array}$ & $\begin{array}{l}\text { - RA } \\
\text { - Gout } \\
\text { - Pseudogout } \\
\text { - Psoriatic arthritis } \\
\text { - AS } \\
\text { - SLE } \\
\text { - Reiter syndrome } \\
\text { - Sarcoidosis } \\
\text { - Rheumatic fever } \\
\text { - Wegener } \\
\text { granulomatosis } \\
\text { - Infectious arthritis } \\
\text { - SBE [37, 38] }\end{array}$ & $\begin{array}{l}\text { 1. It is a septic arthritis until } \\
\text { proven otherwise by the fluid } \\
\text { culture } \\
\text { 2. Pseudosepsis include reactions } \\
\text { to intra-articular injections, } \\
\text { gout, Reiter's syndrome, } \\
\text { leukemic infiltration, and RA } \\
{[37,38]}\end{array}$ \\
\hline
\end{tabular}


Fig. 3.1 Clinical approach for painful peripheral joint

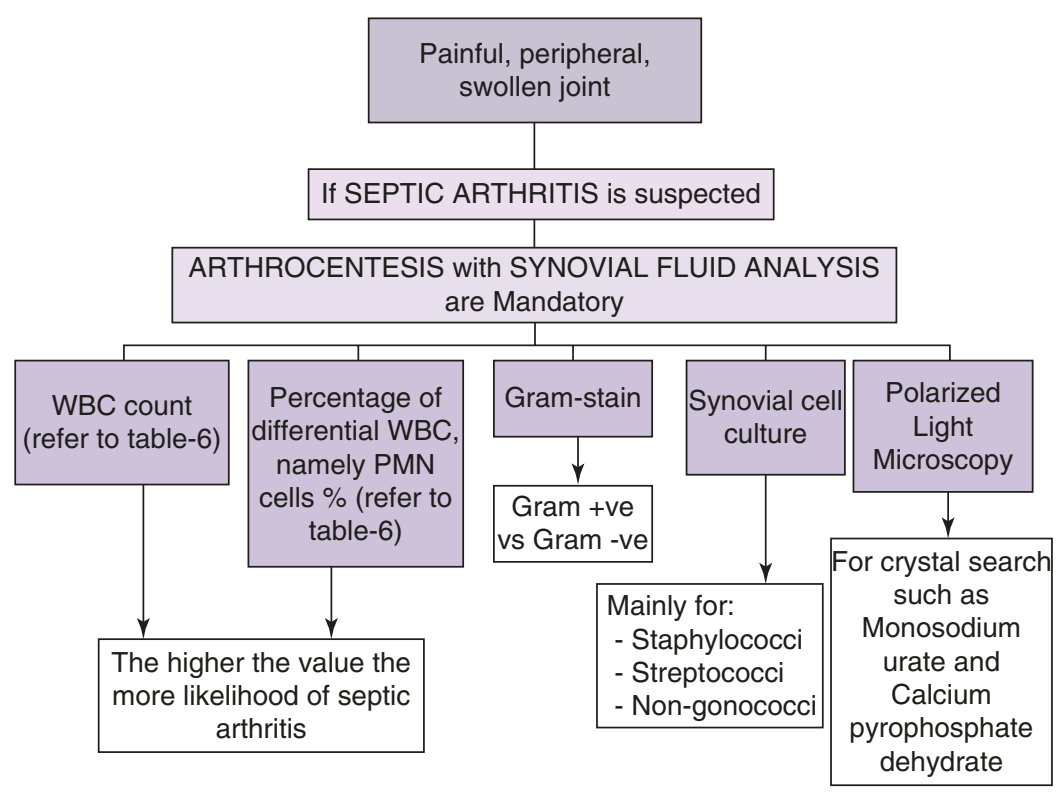

- WBC count $>100,000 / \mu \mathrm{L}$, the LR is 28.0 at $95 \%$ CI.

- Polymorphonuclear (PMN) cells of 90\% are associated with increasing likelihood of septic arthritis of 3.4, while if the percentage of PMN cells is less than $90 \%$, the likelihood decreases down to $0.34(95 \% \mathrm{CI})$ that supports the clinician's suspicion of bacterial arthritis [38, 39].

- Eosinophilic cells in the synovial fluid suggest parasitic infection, allergy, Lyme disease, or neoplasm [40].

- If there is a suspicion of joint involvement by a neoplasm or hematologic malignancy, formal cytological examination should be ordered [38].

- Hemorrhagic effusions may be caused by hemophilia, anticoagulation or other bleeding diathesis, scurvy, trauma, neuropathic arthropathy, and tumors [38].

\subsubsection{Gram Stain}

- It is used to identify common bacterial organisms (Gram-positive versus Gram-negative coverage) for the diagnosis and treatment of septic arthritis.
- It may be the only evidence of infection with fastidious organisms that are not able to grow in culture [41].

- The sensitivity is not known precisely.

- In non-gonococcal bacterial arthritis, it is in range from $50 \%$ to $70 \%$.

- In gonococcal arthritis, it is $<10 \%$ [41].

- The specificity is high when performed and interpreted by an experienced clinician or technician [41].

\subsubsection{Synovial Fluid Culture}

- The synovial fluid samples should be routinely sent for culture for staphylococci followed by streptococci and Gram-negative bacteria (non-gonococcal causes).

- Antibiotics should generally not be given prior to joint aspiration [42, 43].

- The specificity: Positive synovial culture should be indicative of septic arthritis in 100\% of cases with exclusive of contamination and laboratory error [42, 43].

- The sensitivity: It is not known precisely because of the lack of an alternative gold standard. The joint aspirate should be cultured for 
Table 3.7 Gout versus pseudo-gout

\begin{tabular}{l|l|l|l|l}
\hline & Crystal & Shape & Birefringence & $\begin{array}{l}\text { Color of crystals parallel to axis of } \\
\text { red-plate compensator }\end{array}$ \\
\hline Gout & Monosodium urate (MSU) & Needle & Negative & Yellow \\
\hline Pseudogout & $\begin{array}{l}\text { Calcium pyrophosphate } \\
\text { dehydrate (CPPD) }\end{array}$ & $\begin{array}{l}\text { Rhomboid or } \\
\text { rectangular }\end{array}$ & Positive & Blue [48] \\
\hline
\end{tabular}

N. gonorrhoeae or unusual organisms (TB, Lyme disease, or fungal infections) when the history is suggestive $[42,43]$.

\subsubsection{Diagnostic Approach}

- It should be noted that the absence of organisms on Gram stain or a negative subsequent synovial fluid culture does not rule out the diagnosis of septic arthritis especially if clinical suspicion is high. In such condition, an empirical treatment of the case as septic arthritis should be implemented [44-46].

- Moreover, it has been suggested that the "gold standard" for the diagnosis of septic arthritis is the level of clinical suspicion by an expert physician in the management of patients with musculoskeletal disease [35, 45].

- Similarly, another study had concluded that combining Gram stain and culture of synovial fluid with clinical follow-up is the best approach used to detect patients missed by Gram stain and culture alone [36].

\subsubsection{Crystal Search Using Polarized Light Microscopy}

Polarized light microscope (PLM) is a fundamental tool for detection and identification of various types of crystals present in synovial fluid depending on their shape (needle, rhomboid, cigar-shaped, etc.) birefringence, location (intracellular or extracellular), and quantity (scarce or plentiful). The obtained results of PLM help the clinicians in diagnosing and managing a case of monoarthritis. However, the presence of artifacts in microscopic analysis can confuse the inexperienced observer; therefore, a suitable interpre- tation of the synovial fluid analysis using PLM requires at least two experienced observers [47]. The microscopic features of common types of crystals that can differentiate between clinical cases of gout and pseudogout are illustrated in Table 3.7.

\subsection{Summary}

Due to the fact that musculoskeletal symptoms are exceedingly common compared with the prevalence of systemic rheumatic disease, the pretest probability of systemic rheumatic disease in the population is rather low compared with musculoskeletal symptoms that are nearly ubiquitous. Therefore, establishing the diagnosis of a rheumatic disease may require exclusion of other differential diagnoses that present in a similar fashion. Even the disease established-guidelines, which are often used by clinicians, perform poorly during the assessment of a patient presenting with new polyarthritis [49]. As a consequence, widely used laboratory tests can be very specific and permit rapid diagnosis and appropriate management. However, clinicians should be aware of the false-positive tests that may result in inappropriate management and unnecessary concern.

Generally, serum rheumatologic tests are most helpful for confirming a clinically suspected diagnosis. For instance, testing for RF is appropriate when suspecting RA, Sjögren's syndrome, or cryoglobulinemia, whereas ANA testing is highly sensitive for SLE and drug-induced lupus. Although an elevated ESR is a sensitive test for polymyalgia rheumatica and temporal arteritis, its specificity is quite low. In addition, ESR levels are frequently linked to the disease activity in rheumatoid arthritis and may found to be of value for monitoring therapeutic response. However, anti-double-stranded 
DNA antibodies are usually associated with lupus nephritis, and their titer often correlates with disease activity in SLE. On the other hand, cytoplasmic anti-neutrophil cytoplasmic antibody test is highly sensitive and specific for GPA.

In order to increase the utility and decrease the cost-effectiveness of the laboratory testing of rheumatic disease, these tests should be used more selectively and avoid absolute overreliance on lab results. However, a logic combination of the clinical background and the testing results would provide the appropriate diagnosis of the rheumatic conditions. Finally, as Shmerling RH has stated, "the passage of time is one of most useful diagnostic tests as many patients with musculoskeletal symptoms improve over time without a clear diagnosis" [50].

Acknowledgments The authors would like to thank Dr. Waleed Hafiz for his assistance in the development of this chapter.

\section{Abbreviations}

\begin{tabular}{|c|c|}
\hline (IL)-6 & Interleukin-6 \\
\hline AMAs & Anti-mitochondrial antibodies \\
\hline ANA & Antinuclear antibody profile \\
\hline ANCAs & $\begin{array}{l}\text { Anti-neutrophil cytoplasmic } \\
\text { antibodies }\end{array}$ \\
\hline anti-dsDNA & $\begin{array}{l}\text { Anti-double-stranded } \\
\text { antibodies }\end{array}$ \\
\hline anti-gp210 & $\begin{array}{l}\text { Anti-glycoprotein- } 210 \\
\text { antibodies }\end{array}$ \\
\hline anti-p62 & Anti-protien-62 antibodies \\
\hline anti-SCL-70 & Anti-topoisomerase 1 antibodies \\
\hline anti-Th/To & $\begin{array}{l}\text { Antibodies to } \mathrm{Th} / \mathrm{To} \\
\text { ribonucleoprotein }\end{array}$ \\
\hline APRs & Acute phase reactants or proteins \\
\hline AS & Ankylosing spondylitis \\
\hline $\mathrm{C} 4$ and $\mathrm{C} 3$ & Complements \\
\hline C-ANCA & $\begin{array}{l}\text { Cytoplasmic anti-neutrophil } \\
\text { cytoplasmic antibodies }\end{array}$ \\
\hline CI & Confidence interval \\
\hline CRP & C-reactive protein \\
\hline EGPA & $\begin{array}{l}\text { Eosinophilic granulomatosis with } \\
\text { polyangiitis }\end{array}$ \\
\hline ELISA & $\begin{array}{l}\text { Enzyme-linked immunosorbent } \\
\text { assay }\end{array}$ \\
\hline
\end{tabular}

\section{ESR}

GPA

HEp2 cells

HLA-B27

HLA-DR

\section{$\operatorname{IgG}$}

IL-1

INH

LR

MPA

MPA

P-ANCA

PLM

PMN

Pronestyl

RF

RNP

SLE

TNF-alpha

WBC
Erythrocyte sedimentation rate Granulomatous polyangiitis

Human epithelial cell tumor line Human leukocyte antigen B27

Human leukocyte antigen MHC class II

Immunoglobulin G

Interleukin-1

Isoniazid

Likelihood ratio

Microscopic polyangiitis

Myeloperoxidase

Perinuclear anti-neutrophil cytoplasmic antibodies

Polarized light microscope

Polymorphonuclear cells

Procainamide

Rheumatoid factor

Anti-ribonucleic protein antibodies

Systemic lupus erythematosus

Tumor necrosis factor-alpha

White blood cell count

\section{References}

1. Szodoray P, Szabo Z, Kapitany A, Gyetvai A, Lakos G, Szanto S, et al. Anti-citrullinated protein/peptide autoantibodies in association with genetic and environmental factors as indicators of disease outcome in rheumatoid arthritis. Autoimmun Rev. 2010;9(3):140-3.

2. Rose HM, Ragan C, et al. Differential agglutination of normal and sensitized sheep erythrocytes by sera of patients with rheumatoid arthritis. Proc Soc Exp Biol Med. 1948;68(1):1-6.

3. Ragan C. The history of the rheumatoid factor. Arthritis Rheum. 1961;4:571-3.

4. Schlosstein L, Terasaki PI, Bluestone R, Pearson CM. High association of an HL-A antigen, W27, with ankylosing spondylitis. $\mathrm{N}$ Engl $\mathrm{J}$ Med. 1973;288(14):704-6.

5. Stastny P. Mixed lymphocyte cultures in rheumatoid arthritis. J Clin Invest. 1976;57(5):1148-57.

6. Lane SK, Gravel JW Jr. Clinical utility of common serum rheumatologic tests. Am Fam Physician. 2002;65(6):1073-80.

7. Sterling G. Rheumatology secrets. 3rd Edition. Philadelphia, PA; 2002. ISBN: 9780323641869.

8. Simple rule for calculating normal erythrocyte sedimentation rate. $\mathrm{Br}$ Med J. 1983;286(6364): 557-8. 
9. Kushner I, Rzewnicki D, Samols D. What does minor elevation of C-reactive protein signify? Am J Med. 2006;119(2):166. e17-28

10. Gaitonde S, Samols D, Kushner I. C-reactive protein and systemic lupus erythematosus. Arthritis Rheum. 2008;59(12):1814-20.

11. Fincher RM, Page MI. Clinical significance of extreme elevation of the erythrocyte sedimentation rate. Arch Intern Med. 1986;146(8):1581-3.

12. Crowson CS, Rahman MU, Matteson EL. Which measure of inflammation to use? A comparison of erythrocyte sedimentation rate and C-reactive protein measurements from randomized clinical trials of golimumab in rheumatoid arthritis. J Rheumatol. 2009;36(8):1606-10.

13. Ward MM. Relative sensitivity to change of the erythrocyte sedimentation rate and serum C-reactive protein concentration in rheumatoid arthritis. J Rheumatol. 2004;31(5):884-95.

14. van Leeuwen MA, van der Heijde DM, van Rijswijk MH, Houtman PM, van Riel PL, van de Putte LB, et al. Interrelationship of outcome measures and process variables in early rheumatoid arthritis. A comparison of radiologic damage, physical disability, joint counts, and acute phase reactants. J Rheumatol. 1994;21(3):425-9.

15. Kim HA, Jeon JY, An JM, Koh BR, Suh CH. C-reactive protein is a more sensitive and specific marker for diagnosing bacterial infections in systemic lupus erythematosus compared to S100A8/A9 and procalcitonin. J Rheumatol. 2012;39(4):728-34.

16. Wu JY, Lee SH, Shen CJ, Hsieh YC, Yo PH, Cheng $\mathrm{HY}$, et al. Use of serum procalcitonin to detect bacterial infection in patients with autoimmune diseases: a systematic review and meta-analysis. Arthritis Rheum. 2012;64(9):3034-42.

17. Yu J, Xu B, Huang Y, Zhao J, Wang S, Wang H, et al. Serum procalcitonin and C-reactive protein for differentiating bacterial infection from disease activity in patients with systemic lupus erythematosus. Mod Rheumatol. 2014;24(3):457-63. https://doi.org/10 .3109/14397595.2013.844391. Epub 2013 Oct 21. PMID: 24252006.

18. Gabay C, Kushner I. Acute-phase proteins and other systemic responses to inflammation. N Engl J Med. 1999;340(6):448-54.

19. Shmerling RH, Delbanco TL. How useful is the rheumatoid factor? An analysis of sensitivity, specificity, and predictive value. Arch Intern Med. 1992;152(12):2417-20.

20. Lawrence RC, Felson DT, Helmick CG, Arnold LM, Choi H, Deyo RA, et al. Estimates of the prevalence of arthritis and other rheumatic conditions in the United States. Part II. Arthritis Rheum. 2008;58(1):26-35.

21. Shmerling RH, Delbanco TL. The rheumatoid factor: an analysis of clinical utility. Am J Med. 1991;91(5):528-34.
22. van der Heijde DM, van Riel PL, van Rijswijk MH, van de Putte LB. Influence of prognostic features on the final outcome in rheumatoid arthritis: a review of the literature. Semin Arthritis Rheum. 1988;17(4):284-92.

23. Nishimura K, Sugiyama D, Kogata Y, Tsuji G, Nakazawa T, Kawano S, et al. Meta-analysis: diagnostic accuracy of anti-cyclic citrullinated peptide antibody and rheumatoid factor for rheumatoid arthritis. Ann Intern Med. 2007;146(11):797808. https://doi.org/10.7326/0003-4819-146-11200706050-00008. PMID: 17548411.

24. Mjaavatten MD, van der Heijde DM, Uhlig T, Haugen AJ, Nygaard H, Bjorneboe O, et al. Should anticitrullinated protein antibody and rheumatoid factor status be reassessed during the first year of followup in recent-onset arthritis? A longitudinal study. J Rheumatol. 2011;38(11):2336-41.

25. Sihvonen S, Korpela M, Mustila A, Mustonen J. The predictive value of rheumatoid factor isotypes, anticyclic citrullinated peptide antibodies, and antineutrophil cytoplasmic antibodies for mortality in patients with rheumatoid arthritis. J Rheumatol. 2005;32(11):2089-94.

26. Solomon DH, Kavanaugh AJ, Schur PH, American College of Rheumatology Ad Hoc Committee on Immunologic Testing G. Evidence-based guidelines for the use of immunologic tests: antinuclear antibody testing. Arthritis Rheum. 2002;47(4):434-44.

27. Smeenk R, Brinkman K, van den Brink H, Termaat RM, Berden J, Nossent H, et al. Antibodies to DNA in patients with systemic lupus erythematosus. Their role in the diagnosis, the follow-up and the pathogenesis of the disease. Clin Rheumatol. 1990;9(1 Suppl 1):100-10.

28. Tokano Y, Yasuma M, Harada S, Takasaki Y, Hashimoto H, Okumura K, et al. Clinical significance of IgG subclasses of Anti-Sm and U1 ribonucleoprotein antibodies in patients with systemic lupus erythematosus and mixed connective tissue disease. J Clin Immunol. 1991;11(6):317-25.

29. Moder KG. Use and interpretation of rheumatologic tests: a guide for clinicians. Mayo Clin Proc. 1996;71:391-6.

30. Seo P, Stone JH. The antineutrophil cytoplasmic antibody-associated vasculitides. Am J Med. 2004;117(1):39-50.

31. Saeki $\mathrm{T}$, Ito $\mathrm{T}$, Yamazaki $\mathrm{H}$, Imai $\mathrm{N}$, Nishi $\mathrm{S}$. Hypocomplementemia of unknown etiology: an opportunity to find cases of IgG4-positive multiorgan lymphoproliferative syndrome. Rheumatol Int. 2009;30(1):99-103.

32. Guidelines for the initial evaluation of the adult patient with acute musculoskeletal symptoms. American College of Rheumatology Ad Hoc Committee on Clinical Guidelines. Arthritis Rheum. 1996;39(1):1-8. 
33. Al-Shakarchi ICG. The treatment and care of hot, swollen joints. Rheumatol Pract. 2009;7(7):9.

34. Swan A, Amer H, Dieppe P. The value of synovial fluid assays in the diagnosis of joint disease: a literature survey. Ann Rheum Dis. 2002;61(6): 493-8.

35. Dieppe PAH, Swan A. Synovial fluid analysis. Annu Meet Int Soc Technol Assess Health Care Meet 2000; 16 (112).

36. Mathews CJ, Kingsley G, Field M, Jones A, Weston VC, Phillips M, et al. Management of septic arthritis: a systematic review. Ann Rheum Dis. 2007;66(4):440-5.

37. Margaretten ME, Kohlwes J, Moore D, Bent S. Does this adult patient have septic arthritis? JAMA. 2007;297(13):1478-88.

38. Kerolus G, Clayburne G, Schumacher HR Jr. Is it mandatory to examine synovial fluids promptly after arthrocentesis? Arthritis Rheum. 1989;32(3):271-8.

39. Krey PR, Bailen DA. Synovial fluid leukocytosis. A study of extremes. Am J Med. 1979;67(3):436-42.

40. Kortekangas P, Aro HT, Tuominen J, Toivanen A. Synovial fluid leukocytosis in bacterial arthritis vs. reactive arthritis and rheumatoid arthritis in the adult knee. Scand J Rheumatol. 1992;21(6):283-8.

41. Kay J, Eichenfield AH, Athreya BH, Doughty RA, Schumacher HR Jr. Synovial fluid eosinophilia in Lyme disease. Arthritis Rheum. 1988;31(11):1384-9.

42. Dougados M. Synovial fluid cell analysis. Baillieres Clin Rheumatol. 1996;10(3):519-34.
43. Shmerling RH. Synovial fluid analysis. A critical reappraisal. Rheum Dis Clin N Am. 1994;20(2):503-12.

44. Sorlin P, Mansoor I, Dagyaran C, Struelens MJ. Comparison of resin-containing BACTEC plus aerobic/F* medium with conventional methods for culture of normally sterile body fluids. J Med Microbiol. 2000;49(9):787-91.

45. Sharp JT, Lidsky MD, Duffy J, Duncan MW. Infectious arthritis. Arch Intern Med. 1979;139(10):1125-30.

46. Coakley G, Mathews C, Field M, Jones A, Kingsley G, Walker D, et al. BSR \& BHPR, BOA, RCGP and BSAC guidelines for management of the hot swollen joint in adults. Rheumatology. 2006;45(8):1039-41.

47. Kaandorp CJ, Van Schaardenburg D, Krijnen P, Habbema JD, van de Laar MA. Risk factors for septic arthritis in patients with joint disease. A prospective study. Arthritis Rheum. 1995;38(12):1819-25.

48. Martinez-Castillo A, Nunez C, Cabiedes J. Synovial fluid analysis. Reumatol Clin. 2010;6(6):316-21.

49. Harrison BJ, Symmons DP, Barrett EM, Silman AJ. The performance of the 1987 ARA classification criteria for rheumatoid arthritis in a population based cohort of patients with early inflammatory polyarthritis. American Rheumatism Association. J Rheumatol. 1998;25(12):2324-30.

50. Shmerling RH. Diagnostic tests for rheumatic disease: clinical utility revisited. South Med J. 2005;98(7):704-11; quiz 12-3, 28

Open Access This chapter is licensed under the terms of the Creative Commons Attribution 4.0 International License (http://creativecommons.org/licenses/by/4.0/), which permits use, sharing, adaptation, distribution and reproduction in any medium or format, as long as you give appropriate credit to the original author(s) and the source, provide a link to the Creative Commons license and indicate if changes were made.

The images or other third party material in this chapter are included in the chapter's Creative Commons license, unless indicated otherwise in a credit line to the material. If material is not included in the chapter's Creative Commons license and your intended use is not permitted by statutory regulation or exceeds the permitted use, you will need to obtain permission directly from the copyright holder. 